\title{
PENURUNAN DEPRESI PADA LANSIA HARGA DIRI RENDAH MELALUI TERAPI AKTIVITAS KELOMPOK DAN TERAPI KOGNITIF
}

\author{
Suzanna $^{1 *}$, Mustikasari $^{2}$, Ice Yulia Wardani ${ }^{2}$ \\ 1. STIKES Muhammadiyah Palembang, Sumatera Selatan 30116, Indonesia \\ 2. Fakultas Ilmu Keperawatan Universitas Indonesia, Depok 16424, Indonesia \\ *E-mail: anna_nice84@yahoo.com
}

\begin{abstract}
Abstrak
Penelitian ini bertujuan untuk mengidentifikasi penurunan depresi pada lansia harga diri rendah melalui Terapi Aktivitas elompok (TAK) stimulasi persepsi dan Terapi Kognitif Perilaku. Desain penelitian menggunakan quasi experiment with pre post test control group, dengan sampel berjumlah 28 orang pada kelompok intervensi dan 28 orang pada kelompok kontrol. Alat pengumpul yang digunakan Geriatric Depression Scale (GDS). Data dianalisis menggunakan uji T-Test. Hasil penelitian menunjukkan ada penuruan bermakna kondisi depresi lansia harga diri rendah pada kedua kelompok dengan penurunan sebesar 67,4\% kelompok intervensi dan 31,9\% kelompok kontrol ( $p$ value < 0,05), dan ada hubungan bermakna antara karakteristik lansia (jenis kelamin, pendidikan, status perkawinan, pekerjaan dan penyakit fisik penyerta) dengan depresi pada lansia harga diri rendah ( $p$ value $<0,05)$. TAK stimulasi persepsi harga diri rendah dan terapi kognitif perilaku direkomendasikan untuk depresi pada lansia harga diri rendah.
\end{abstract}

Kata kunci : depresi, harga diri rendah, Terapi Aktivitas Kelompok, terapi kognitif perilaku

\begin{abstract}
Decrease in Elderly Depression through Therapy Low Self-Esteem Group Activities and Cognitive Therapy. The aim of this study was to determine the influence of Therapy of Group Activities (TGA) stimulatiing low self esteem perception and Cognitive Behavioral Therapy (CBT) for depression in elderly low self esteem. The research design was quasi experiment with pre-post test control group. The sample of this research are 28 respondents in the intervention group and 28 respondents in control group. Data collection with Geriatric Depression Scale (GDS) and were analyzed using T-test. The results showed significant decrease of elderly depression low self-esteem in both groups with a decrease of $67.4 \%$ intervention group and $31.9 \%$ of controls ( $p$ value <0.05) and significant relationship exists between elderly characteristics (gender, education, marital status, employment and comorbid physical illness) with depression in elderly low self-esteem ( $p$ value <0,05). Therefore, TGA stimulating low self-esteem and perception of cognitive behavioral therapy are recommended for depression in the elderly low self esteem.
\end{abstract}

Keywords: cognitive behavioural therapy, depression, low self esteem, Therapy of Group Activities

\section{Pendahuluan}

Depresi menjadi salah satu masalah gangguan mental yang sering ditemukan pada lansia. Prevalensi depresi pada lansia di dunia sekitar 8-15\% (Rebecca, 2010). Berdasarkan hasil dari Riset Kesehatan Dasar 2007 didapatkan data usia tertinggi pada kelompok umur lebih dari 75 tahun dengan insiden depresi $33,7 \%$
(Depkes, 2008). Prevalensi depresi berkisar $10-15 \%$ dari populasi lansia dan diduga $60 \%$ dari pasien lansia di Rumah Sakit dan Panti Jompo seringkali gejala depresi dianggap sebagai bagian dari proses menua (Budi, 2011). Angka kejadian depresi pada lansia di atas 65 tahun diperkirakan meningkat berkisar 10$30 \%$ dengan keadaan jarang mendapat terapi (Rebecca, 2010; Suardiman, 2011). 
Upaya mengatasi depresi lansia secara umum terdiri dari upaya secara medis dan keperawatan. Praktik perawat jiwa menurut Videbeck (2008) yaitu melaksanakan fungsi pada tingkat dasar dan fungsi pada tingkat lanjutan, dimana pada tingkat lanjutan hanya dapat dilakukan perawat spesialis bersertifikat dalam keperawatan jiwa.

Psikoterapi untuk mengatasi masalah depresi sudah banyak dikembangkan di beberapa penelitian luar negeri dalam bentuk terapi kognitif dengan modifikasi terapi perilaku. Bentuk terapi yang dikenal dengan Cognitif Behaviour Therapy (CBT). Penelitian yang lain oleh Peng, Huang, Chen, dan Lu, (2009) menguraikan penerapan CBT pada usia lanjut dapat meningkatan sosialisasi, restrukturisasi kognitif dan penguatan dalam penerimaan konsep penuaan. Penerapan terapi kognitif pada masalah depresi dan kecemasan diperoleh hasil perubahan respon emosional yang signifikan setelah pemberian terapi (Hayers, et al., 2007).

Hasil penelitian menunjukkan CBT sangat membantu orang lanjut usia dalam mengatasi masalah depresi dan kecemasan yang dirasakan oleh banyak lansia (Jenny, 2009). Laidlaw (2003) menguraikan bahwa CBT untuk lansia memiliki sedikit berbeda dengan CBT untuk anak, remaja serta dewasa awal. Adapun perbedaanya adalah pada proses pendekatan antara terapi dengan lansia terutama dalam hal kecepatan memberikan terapi, karena lansia membutuhkan penyesuaian terlebih dahulu, namun tetap memberikan efek penurunan depresi lansia. Buku saku yang dibuat oleh Ceri (2009) menjelaskan bahwa CBT depresi tepat untuk lansia dengan dilakukan pelatihan bagi terapis dan lansia.

\section{Metode}

Penelitian ini merupakan penelitian kuantitatif dengan desain penelitian Quasi Exsperimental pre post test with control group dengan pemberian intervensi berupa TAK stimulasi persepsi harga diri rendah dan terapi kognitif perilaku pada lansia yang mengalami depresi. Sampel penelitian adalah lansia dengan harga diri rendah di suatu panti Kabupaten di Sumatera Selatan, dengan kriteria lansia yang telah di skrining harga diri rendah, bisa membaca dan menulis, tidak mengalami kecacatan. Tempat penelitian dilakukan di suatu panti Kabupaten di Sumatera Selatan. Penelitian ini menggunakan prinsip etik yang meliputi menghormati martabat manusia (respect for person), berbuat baik (beneficence), tidak merugikan (non maleficence) dan keadilan (justice) (Polit \& Hungler, 2006). Penelitian ini sudah melalui uji lolos etik untuk kelayakan penelitian oleh tim komite etik Fakultas Ilmu Keperawatan Universitas Indonesia. Alat pengumpul yang digunakan Geriatric Depression Scale (GDS).

Tahapan pengambilan data dimulai dengan menjelaskan tujuan dan manfaat dari penelitian kepada responden. Setelah itu responden diminta menandatangani Informed consent tentang kesediaan dan menyetujui menjadi responden dalam penelitian. Pre test dilakukan pada masing-masing responden dengan mengisi kuesioner, di akhir dilakukan post test setelah dilakukan TAK stimulasi persepsi dilanjutkan dengan terapi kognitif perilaku.

Kuesioner pre test dan post test serta buku kerja kemudian dikumpulkan oleh peneliti untuk dilakukan pengecekan isian tersebut, apabila ditemukan isian dari kuesioner atau buku kerja yang belum terisi, maka dilakukan validasi kepada responden. Setelah terisi semua maka siap untuk diolah datanya. Pengolahan dilakukan melalui tahapan editing, coding, scoring, processing, dan cleaning. Analisis univariat dilakukan pada karakteristik lansia (usia, jenis kelamin, pendidikan, pekerjaan dan penyakit fisik) dan variabel dependent (depresi). 
Peneliti melakukan uji kesetaraan antara kelompok yang mendapat TAK stimulasi persepsi HDR dan CBT dengan kelompok yang mendapat TAK Spesialis HDR. Analisis perubahan kondisi depresi setelah intervensi menggunakan uji Dependent t-test (Paired sample t-test). Sedangkan analisa perbedaan kondisi depresi setelah mendapatkan kelompok yang mendapat TAK Spesialis HDR \& CBT dengan kelompok yang mendapat TAK Spesialis HDR menggunakan uji t-test Independent.

\section{Hasil}

Lansia yang mengalami depresi rata-rata berusia 69,1 tahun, berjenis kelamin wanita $58,9 \%$; berpendidikan rendah $78,6 \%$, status perkawinan menikah 71,4\%, tidak bekerja 85,7, dan sakit $80,36 \%$. Pengaruh TAK Stimulasi Persepsi Harga Diri Rendah dan CBT terhadap depresi pada lansia harga diri rendah. Pada Tabel 1, hasil uji statistik menunjukkan ada penurunan yang signifikan kondisi depresi $(p<0,05)$. Hasil tabel 2 terdapat hubungan jenis kelamin, pendidikan, pekerjaan, status pernikahan, penyakit fisik, dengan depresi. Hanya usia yang tidak berhubungan dengan depresi Lansia.

\section{Pembahasan}

Hubungan Karakteristik lansia dengan Depresi. Usia tidak memiliki hubungan dengan depresi pada lansia harga diri rendah karena depresi dapat terjadi pada semua umur dan dipengaruhi oleh faktor predisposisi yaitu faktor genetik, kerusakan organik, faktor presipitasi yaitu tentang biologis, psikologis, dan sosial serta faktor resiko (Stuart Laraia, 2007).

Jenis kelamin memiliki hubungan dengan depresi pada lansia harga diri rendah dikarenakan perempuan lebih rentan untuk mengalami stres dibandingkan dengan laki-laki. Pe- rempuan lebih sensitif terhadap hormon yang menyebabkan stres saat mengalami kecemasan serta kurang mampu untuk beradaptasi terhadap tingkat stres yang lebih tinggi. Perbedaan antara tingkat depresi pada pria dan perempuan mencerminkan perilaku berdasarkan peran gender dalam kehidupan sehari-hari.

Pendidikan memiliki hubungan terhadap depresi. Pendidikan memengaruhi kemampuan lansia dalam menyelesaikan masalah serta beradaptasi dengan semua perubahan yang dihadapi. Semakin tinggi tingkat pendidikan lansia maka semakin baik pula cara berpikirnya serta baik pula kemampuan lansia dalam merespon masalah ataupun stres. Hal ini dapat diamati oleh lansia pada saat pelaksanaan TAK Stimulasi Persepsi Harga Diri Rendah dan Terapi Kognitif Perilaku, sebagian besar lansia yang memiliki pendidikan mampu bercerita mengenai pengalaman tentang dirinya, cara menyelesaikan masalah serta saling membagi semangat dengan lansia lainnya.

Status perkawinan memiliki hubungan yang bermakna dengan depresi. Stressor lansia yang mengalami depresi adalah kehilangan pasangan, jauh dari anak dan kerabat ataupun putusnya hubungan dengan orang terdekat. Hubungan keluarga memilki peranan yang kuat dalam hal kasih sayang, perhatian serta dukungan dalam menghadapi setiap masalah yang terjadi dengan bersama-sama mencari penyelesaian masalah.

Pekerjaan memiliki hubungan yang bermakna terhadap depresi pada lansia harga diri rendah. Lansia tidak bisa melakukan kegiatan yang menghasilkan uang untuk memenuhi kebutuhan hidup pribadinya, yang memengaruhi sumber kopingnya dalam mengatasi masalah yang ada pada diri lansia tersebut seperti kebutuhan akan kesehatan, kebutuhan akan rekreasi dan sebagainya. 
Tabel 1. Analisis Penurunan Depresi Lansia pada Kelompok Kontrol dan Intervesi Sebelum dan Sesudah dilakukan TAK Stimulasi Persepsi Harga Diri Rendah dan Terapi Kognitif Perilaku (N=56)

\begin{tabular}{llllllllll}
\hline \multicolumn{1}{c}{ Kelompok } & Variabel & $\mathbf{N}$ & Mean & \% & $\begin{array}{c}\text { Std. } \\
\text { Dev }\end{array}$ & Min & Max & T & p \\
\hline \multirow{2}{*}{ Skor Depresi } & & & & & & & & & \\
Intervensi & Sebelum & 28 & 10,96 & & 1,2 & 8 & 13 & & \\
& Sesudah & 28 & 3,57 & & 0,84 & 2 & 5 & 29,752 & $0,000^{*}$ \\
& Selisih & & 7,39 & 67,4 & 1,31 & 5 & 10 & & \\
\multirow{2}{*}{ Kontrol } & Sebelum & 28 & 11,18 & & 1,12 & 9 & 12 & & \\
& Sesudah & 28 & 7,61 & & 1,29 & 6 & 9 & 10,788 & $0,000^{*}$ \\
& Selisih & & 3,57 & 31,9 & 1,75 & 0 & 6 & & \\
\hline
\end{tabular}

Penyakit fisik penyerta memiliki hubungan yang bermakna terhadap depresi pada lansia harga diri rendah. Secara fisiologis penurunan fungsi fisik pada lansia dapat terjadi penurunan fungsi seperti penglihatan, pendengaran, gangguan pada sistem muskuloskletal, kardiovaskuler dan perkemihan, yang akan berdampak munculnya stressor pendukung terjadinya depresi karena lansia selalu memikirkan kondisi yang dialami terkait penyakit yang dideritanya walaupun penyakit ini merupakan hal yang wajar dialami oleh lansia.

\section{Pengaruh TAK SP HDR dan CBT terhadap} Depresi pada lansia harga diri rendah. Penurunan kondisi depresi pada lansia harga diri rendah setelah diberikan TAK Stimulasi Persepsi HDR dan CBT. Hasil penelitian ini setara dengan penelitian yang dilakukan oleh Peng, et al. (2009) penerapan CBT pada usia lanjut dapat menurunkan depresi. Gorenstein dan Papp (2007) menjelaskan bahwa CBT dapat menurunkan kecemasan. Penelitian lain tentang penerapan terapi kognitif perilaku yang spesifik pada masalah depresi dan kecemasan diperoleh hasil perubahan respon emosional yaitu perubahan mood yang signifikan setelah pemberian terapi (Hayers, et al., 2007). Penelitian sebelumnya menguraikan efek pemberian perawatan depresi bagi usia lanjut dengan CBT bahwa adanya perubahan yang signifikan terhadap tingkat depresi dari depresi sedang menjadi tidak depresi yang ditandai dengan perasaan nyaman serta rileks. Sedangkan Ayers, et al. (2011) menjelaskan hasil penelitiannya terapi CBT belum berhasil menurunkan compulsive pada geriatri dengan compulsive hoarding, sehingga perlu dipikirkan terapi yang lainnya.

Laidlaw (2008) salah satu terapi untuk mengatasi masalah depresi pada lansia dengan terapi kognitif perilaku dengan pendekatan restrukturisasi kognitf dengan strategi A-B-C-D dengan membutuhkan waktu yang cukup lama, namun tetap memberikan efek penurunan tingkat depresi lansia. Terapi kognitif yang dilakukan oleh Prasetya (2010) tentang pengaruh Cognitive Therapy terhadap depresi dengan harga diri rendah mengalami penurunan yang bermakna yang sebelumnya 3,36 poin menjadi 1,18 poin setelah mendapat $\mathrm{CT}$ dan senam latih otak.

Arjadi (2012) menyatakan terapi kognitif perilaku (CBT) untuk mengatasi depresi lansia melalui pemberian terapi dengan tiga orang lansia didapatkan penurunan depresi yang cukup baik dengan mampu mengenali depresi, memonitor perasaan, latihan relaksasi, memecahkan masalah, mengenali pikiran negatif dan restrukturisasi pikiran.

Berdasarkan hasil penelitian yang terkait terdapat kesamaan yaitu dalam hal pemberian terapi kognitif perilaku yang spesifik untuk usia lanjut dengan proses pendekatan restruk- 
turisasi kognitf dan pendekatan proses dengan komunikasi terapeutik. Penelitian lansia di Indonesia terdapat kesamaan dengan hasil peneliti dalam hal karakteristik lansia di Indonesia yang tidak terlalu berbeda misalnya budaya, sosial ekonomi serta pandangan hidup. Penelitian yang dilakukan di China menunjukkan CBT dengan menggunakan budaya dapat memengaruhi keberhasilan dalam menurunkan depresi (Williams \& Haarhoff, 2006).

Konsep dasar terapi kognitif perilaku yang diuraikan oleh (Laidlaw, 2003; Wilson, 2010) mengenai strategi dasar dalam restrukturisasi kognitf dengan A-B-C-D (antecedent, belief, consequences, dispute, evaluation). Bentuk pemikiran yang negatif akan memberikan sikap pesimis diri sehingga muncul perilaku yang cenderung menyalahkan diri sendiri (Pervin, 2010; Copel, 2007; Videbeck, 2008, Yosep, 2007).

\section{Kesimpulan}

Lansia yang mengalami depresi rata-rata berusia 69,1 tahun, lebih dari setengah berjenis kelamin perempuan dengan tingkat pendidikan sebagian besar berpendidikan (sekolah dasar). Status perkawinan sebagian besar telah menikah dengan keadaan pekerjaan sekarang

Tabel 2. Hubungan usia, jenis kelamin, pendidikan, pekerjaan, status pernikahan, penyakit fisik, dg depresi pada lansia HDR $2013(\mathrm{~N}=56)$

\begin{tabular}{|c|c|c|c|c|c|}
\hline \multirow{2}{*}{ Kelompok } & \multirow{2}{*}{ Karakteristik } & \multicolumn{4}{|c|}{ Skor Depresi } \\
\hline & & $\mathbf{N}$ & mean & SD & $\mathbf{p}$ \\
\hline Intervensi & Usia & 28 & 10,964 & 1,201 & 0,783 \\
\hline Kontrol & Usia & 28 & 11,176 & 1,142 & 0,575 \\
\hline \multirow[t]{2}{*}{ Intervensi } & laki-laki & 12 & 10,75 & 1,288 & \multirow[b]{2}{*}{$0,000^{*}$} \\
\hline & Perempuan & 16 & 11,125 & 1,147 & \\
\hline \multirow[t]{2}{*}{ Kontrol } & laki-laki & 11 & 11,00 & 1,34 & \multirow[b]{2}{*}{$0,000^{*}$} \\
\hline & Perempuan & 17 & 11,29 & 0,99 & \\
\hline \multirow[t]{2}{*}{ Intervensi } & Sekolah & 22 & 10,255 & 1,327 & \multirow[t]{2}{*}{$0,000^{*}$} \\
\hline & Tidak Sekolah & 6 & 11,000 & 0,632 & \\
\hline \multirow{2}{*}{ Kontrol } & Sekolah & 22 & 10,091 & 1,109 & \multirow{2}{*}{$0,000^{*}$} \\
\hline & Tidak Sekolah & 6 & 11,500 & 1,125 & \\
\hline \multirow[t]{2}{*}{ Intervensi } & Bekerja & 4 & 10,500 & 1,000 & \multirow[t]{2}{*}{$0,000^{*}$} \\
\hline & Tidak Bekerja & 24 & 11,042 & 1,233 & \\
\hline \multirow[t]{2}{*}{ Kontrol } & Bekerja & 4 & 10,250 & 1,500 & \multirow[t]{2}{*}{$0,000^{*}$} \\
\hline & Tidak Bekerja & 24 & 11,333 & 1,007 & \\
\hline \multirow[t]{2}{*}{ Intervensi } & Kawin & 4 & 10,971 & 1,248 & \multirow[t]{2}{*}{$0,000^{*}$} \\
\hline & Belum Kawin & 14 & 11,250 & 0,957 & \\
\hline \multirow[t]{2}{*}{ Kontrol } & Kawin & 12 & 11,000 & 1,265 & \multirow[t]{2}{*}{$0,000 *$} \\
\hline & Belum Kawin & 16 & 11,417 & 0,900 & \\
\hline \multirow[t]{2}{*}{ Intervensi } & Sakit & 27 & 3,56 & 0,85 & \multirow[t]{2}{*}{$0,000 *$} \\
\hline & Tidak Sakit & 1 & 4,00 & & \\
\hline \multirow[t]{2}{*}{ Kontrol } & Sakit & 28 & 7,61 & 1,29 & \multirow[t]{2}{*}{$0,000^{*}$} \\
\hline & Tidak Sakit & 0 & 0 & 0 & \\
\hline
\end{tabular}


sebagian besar tidak bekerja dan sebagian besar lansia memiliki penyakit fisik penyerta. Terdapat hubungan yang bermakna antara jenis kelamin, riwayat pendidikan, status perkawinan, pekerjaan dan penyakit fisik penyerta dengan depresi pada lansia harga diri rendah.

Kondisi depresi sesudah diberikan TAK stimulasi persepsi harga diri rendah dan Terapi Kognitif Perilaku mengalami perbaikan dari kondisi depresi ringan menjadi tidak depresi dan depresi sedang menjadi depresi ringan. Kombinasi TAK stimulasi persepsi harga diri rendah dan terapi kognitif lebih baik dibandingkan TAK stimulasi harga diri rendah saja.

Keberhasilan dalam menurunkan depresi ini perlu didukung dengan program Pemerintah untuk menurunkan depresi pada lansia. Selain itu, diperlukan kerjasama puskemas dan pihak pengelola panti dalam kegiatan yang memotivasi lansia untuk bersosialisasi dan menjaga kebesihan diri yang dilakukan oleh petugas sosial panti (DN, KN, TN).

\section{Referensi}

Ayers, C.R., Wetherell, J.L., Golshan, S., \& Saxene, S. (2011). Cognitive behavioral therapy for geriatric compulsive hoarding, Behavioral Research and Therapy, 49 (10), 689-694.

Arjadi, R. (2012). Cognitive behaviour therapy depresi lansia (Tesis, Program Pascasarjana Psikologi). Program Pascasarjana Fakultas Psikologi Universitas Indonesia, Jakarta, Indonesia.

Boedhi, D.R. (2011). Buku Ajar Geriatic (Ilmu Kesehatan Lanjut Usia) edisi ke - 4.Jakarta : Balai Penerbit FKUI Ceri, Evans (2009). Handbook of behavioral and cognitive therapies with older adults. International Psychogeriatrics British journal of clinical Psychology. Diperoleh dari http://www. bpsjournals.co.uk
Copel, L.C. (2007). Kesehatan Jiwa dan Psikiatri: pedoman klinis perawat. Jakarta: Penerbit Buku Kedokteran EGC.

Depkes RI. (2008). Riset kesehatan dasar 2007. Jakarta: Balitbang Depkes RI.

Gorenstein, E.E., \& Papp, L.A. (2007). Cognitivebehavioral therapy for anxiety in the elderly. Curr Psychiatry Rep, 9 (1), 20-25. Doi: 10.1007/S11920-007-0005-y

Jenny, G.. (2009). CBT is helpful for older peole; study. Medical Sciences Trade Journal Australian. Diperoleh dari http://search.proqu est.com/docview/195127755? accountid $=17242$

Laidlaw, K. Thompson, L.W., Gallegher Thompson, D.\& Dick-Siskin, L. (2003) Cognitive Behaviour Therapy with Older people. Chrisshetr: Jhon Wilwy \& Sons

Maryam, et al. (2008). Mengenal usia lanjut dan perawatannnya. Jakarta. Salemba Medika.

Peng, X.D., Huang, C.Q., Chen, L.J., \& Lu, Z.C. (2009). Cognitive behavioural therapy and reminiscence techniques for the treatment of depression in the elderly: A systematic review, The Journal of International Medical Research, 37(4), 975-982.

Pervin, J. (2010). Psikologi Kepribadian: Teori dan Penelitian. Edisi sembilan. Jakarta. Kencana Media Grup.

Polit, D.F, Beck, C.T \& Hungler, B.P. (2006). Essential of nursing research: Methods apprasial and utilization. Six edition. Philadelphia: lippincott. William \& Wilkins.

Prasetya, A.S., Hamid A.Y., \& Susanti, H. (2010). Pengaruh terapi kognitif dan senam latihan otak terhadap tingkat depresi dengan harga diri rendah pada klien lansia di Panti Tresna Wreda Bekti Yuswa Natar Lampung (Tesis, tidak dipublikasikan). Fakultas Ilmu Keperawatan Universitas Indonesia, Depok Jawa Barat, Indonesia. 
Rebecca. (2010). Solusi praktis mengenali, mengatasi, dan mengantisipasi depresi. Jakarta: Gramedia

Stuart, G.W, \& Laraia M.T. (2007). Principles and practice of psychiatric nursing (7th Ed.) Philadelphia: Mosby. Inc.

Suardiman, S.P. (2011). Psikologi usia lanjut (Edisi pertama). Yogyakarta: Gajah Mada University Press.

Yosep, I. (2007). Keperawatan Jiwa. Bandung: Refika Aditama.
Videbeck, S.L. (2008). Buku ajar keperawatan jiwa (diterjemahkan oleh Sheila L). Cetakan I. Jakarta: Penerbit Buku Kedokteran EGC.

Williams, M., \& Haarhoff, B.A. (2006). Case study of an elderly chinese woman with generalised anxiety disorder. New Zealand Journal of Psychology, 35 (3), 153-162. Retrieved from http://www.researchgate.net/publication/26470 7556. 